\title{
PENGALAMAN ODHA REMAJA PEREMPUAN MINUM ARV DI KLINIK VCT RSUD CILACAP
}

\author{
Dhiah Dwi Kusumawati), Frisca Dewi Yunadi²), Rochany Septiyaningsih ${ }^{3)}$ \\ 1dhiahdwi@gmail.com, ${ }^{2}$ friscadewi86@gmail.com, ${ }^{3}$ rochanyseptiyaningsih87@gmail.com \\ ${ }^{123)}$ Prodi D3 Kebidanan STIKES Al Irsyad Al Islamiyyah Cilacap \\ Jl. Cerme No. 24 Cilacap
}

\begin{abstract}
Abstrac
Teenagers aged 15-24 are a group vulnerable to HIV infection. Data from the Ministry of Health in 2015 showed that HIV-infected adolescents numbered 28,060 people (15.2 percent). A total of 2089 people (3 percent) have already had AIDS. Based on data obtained in 2013-2017, those suffering from HIV / AIDS in Cilacap Regency reached 53 cases. Various obstacles experienced by PLWHA in accessing ARVs, including limited health services and routine counseling that require money. This study aims to reveal the experience of young people living with HIV in drinking ARV in the VCT clinic in Cilacap Hospital. This research is qualitative with descriptive phenomenological approach and thematic analysis. All informants in this study carried out various stages of treatment management and continued to adhere to taking ARVs so that they remained healthy and underwent daily activities. Motivation from yourself and family support and health and environmental staff encourage you to continue taking ARVs.
\end{abstract}

Keywords: $A R V, H I V / A I D S$, Adolescents

\begin{abstract}
Abstrak
Kalangan remaja berusia 15-24 tahun merupakan kelompok yang rentan terinfeksi HIV. Data Kementerian Kesehatan tahun 2015 menunjukkan, remaja yang terinfeksi HIV berjumlah 28.060 orang (15,2 persen). Sebanyak 2089 orang (3 persen) di antaranya sudah dengan AIDS. Berdasarkan data yang didapatkan tahun 2013-2017 yang menderita HIV/AIDS di Kabupaten Cilacap mencapai 53 kasus. Hambatan yang sering dialami ODHA dalam memperoleh ARV pelayanan kesehatan yang terbatas dan konseling rutin yang membutuhkan biaya. Penelitian ini bertujuan untuk mengungkap pengalaman ODHA remaja dalam minum ARV. Penelitian ini kualitatif dengan pendekatan fenomonologi deskriptif dan dianalisis tematik. Semua informan dalam penelitian ini melakukan berbagai tahapan penatalaksanaan pengobatan dan tetap patuh minum ARV. Motivasi dari diri sendiri dan dukungan keluarga serta petugas kesehatan dan lingkungan sekitar mendorong untuk tetap minum ARV.
\end{abstract}

Kata kunci: $A R V, H I V / A I D S$, Remaja

\section{Pendahuluan}

Human Immunodeficiency Virus (HIV) biasanya dapat ditularkan melalui kontak secara langsung antara lapisan kulit dalam (lapisan mukosa)seperti darah, sperma, cairan vagina, dan ASI. Penularan dapat terjadi melalui hubungan intim (vaginal, anal, ataupun oral), transfusi darah, penggunaan jarum suntik bergantian, tranplasenta dari ibu ke bayi. ${ }^{[1]}$

Penggunaan ARV (antiretroviral) pada pasien dengan hasil tes HIV positif merupakan upaya untuk memperpanjang umur harapan hidup
ODHA (orang dengan HIV AIDS). ARV berfungsi untuk menangani infeksi dengan cara memperlambat proses reproduksi HIV yang ada dalam tubuh. Penggunaan ARV yang efektif digunakan dalam bentuk kombinasi, bukan hanya untuk menyembuhkan, tetapi dapat dipergunakan untuk memperpanjang usia harapan hidup ODHA, membuat mereka lebih sehat, dan lebih produktif dengan mengurangi viraemia dan meningkatkan jumlah sel-sel CD4. ${ }^{[2]}$ Kendala yang sering dijumpai oleh ODHA dalam memperoleh ARV, 
antara lain pelayanan kesehatan yang terbatas dan konseling rutin yang membutuhkan biaya. Pemakaian ARV dalam waktu yang lama menimbulkan rasa bosan, kurang displin dan kekhawatiran efek samping. Perilaku ODHA dengan pola hidup yang tidak teratur, stigma dan diskriminasi orang lain merupakan faktor penghambat lain yang dalam penggunaan ARV. [3]

Ketidakpatuhan dalam penggunaan ARV dapat dipengaruhi dari social dan kebudayaan masyarakat . Perspektif sosial dapat digunakan dalam pemahaman bahwa kesehatan dan pelayanan kesehatan tidak hanya dijadikan permasalahan medis, tetapi juga permasalahan sosial. Pendekatan sosial dan pendekatan medis dapat dilakukan bersama, ditekankan tidak hanya pada proses sosial terjadinya suatu penyakit dan sakit, tetapi juga pada intervensi didalam struktur sosial dan budaya untuk pencegahan atau bahkan pengobatan penyakit tersebut. ${ }^{4}$ Melihat fenomena tersebut, maka peneliti tertarik untuk mengungkap pengalaman ODHA remaja minum ARV diklinik VCT RSUD Cilacap.

\section{Metode Penelitian}

Penelitian ini menggunakan metode penelitian kualitatif dengan pendekatan fenomenologi deskriptif untuk melihat pengalaman ODHA remaja dalam minum ARV di klinik VCT RSUD Cilacap. Pada penelitian ini pengambilan informan diambil secara purposive sampling dan didapatkan sampel sebanyak 2 informan.

Penelitian dilakukan dengan wawancara mendalam yang kemudian data dilakukan analisis menggunakan analisis tematik.

\section{Hasil dan Pembahasan}

Usia informan dalam penelitian ini dalam rentang usia 19-20 tahun. Jumlah informan 2 dikarenakan yang bersedian menjadi informan hanya dua informan. Seluruh informan beragama Islam dengan latar belakang pendidikan SMP. Informan dalam penelitian ini bekerja swasta. Informan ini rata-rata didiagnosa HIV/AIDS 1-2 tahun yang lalu dan telah mengkonsumsi ARV langsung setelah dinyatakan positif.

Hasil penelitian menemukan tema yang memaparkan pengalaman remaja dalam minum ARV, diantaranya:

Pemeriksaan CD4 dilakukan pada pasien HIV/AIDS positif sebelum dan sesudah konsumsi ARV. Informan melakukan pemeriksaan darah CD4 sebelum dan sesudah minum ARV, pemeriksaan CD4 dilakukan setelah minum ARV 3-6 bulan sekali. Informan 1 dan 2 menyatakan melakukan cek CD4 setiap 3 bulan sekali, seperti dijelaskan berikut ini:

“....ya dicek mba hasilnya lumayan ada kenaikan selama setahun ini sama rutin 3 bulan sekali..."

( informan 1)

“.....aku dah 2 tahun ini Alhamdulillah selalu cek 3 bulan sekali terus rutin ya hasilnya ya lumayan ada kenaikan...." (informan 2)

Hasil penelitian ini menyatakan bahwa seluruh informan pemeriksaan darah dan CD4, Hal ini juga diungkapkan oleh petugas klinik bahwa pengecekan rutin CD4 bagi ODHA. Penelitian mengenai adanya pemeriksaan CD4 setelah mengkonsumsi ARV pernah dilakukan oleh Rahmadini, Retnosari (2008). Penelitian itu membahas sebagian besar ODHA akan mengalami kenaikan jumlah CD4 setelah pengobatan ARV 6-12 bulan. [5]

Konseling merupakan bagian dari VCT dan dilakukan oleh tenaga kesehatan. VCT adalah voluntary counselling and testing atau bisa diartikan sebagai konseling dan tes HIV sukarela (KTS). Layanan ini bertujuan untuk membantu pencegahan, perawatan, serta pengobatan bagi penderita HIV/AIDS. 
VCT bisa dilakukan di puskesmas atau rumah sakit maupun klinik penyedia layanan VCT. Dua informan pernah VCT dan merasakan manfaatnya saat berkonsultasi mengenai penyakit yang sedang dialami seperti yang diungkapkan oleh kedua informan sebagai berikut:

“ .....awalnya takut banget pas suruh masuk ruang konseling karna malu tapi terus kita diperlakukan sopan dan identitas kita katanya terjamin aman lah....disitu aku dikasih pengetahuan penyakit ini terus emm dikasih tau cara minum obatnya apalagi ya...(sambil lihat ke atas eternit) oh iya ma dikasih tau kalau ingin menikah dan punya anak disarankan ngikutin program yang disini..." (informan 1)

“....aku kesini langsung ada ibu- ibu yang disini nyuruh masuk terus ketemu bapak-bapak diomongin tentang penyakitnya, obatnya terus program yang disini, ya Alhamdulillah bikin lebih tenang..." (informan 2)

Hasil penelitian ini menyatakan bahwa seluruh informan menerima konseling. Konseling ini dilakukan oleh petugas klinik VCT setiap pengambilan ARV dan pengecekan CD4. Penelitian tentang konseling pernah dilakukan oleh Permatasari (2014) menyimpulkan bahwa ODHA sebelum melakukan terapi ARV diberi konseling untuk meningkatkan kepatuhan dalam minum ARV. ${ }^{[6]}$

Alur penatalaksanaan akses ARV yang dijalani informan yaitu penjelasan gambaran pengobatan yang dilakukan oleh informan mulai dari pemahaman tentang pengobatan, prosedur pengambilan obat, eek samping obat, dan upaya mengatasi eek samping. Informan dalam penelitian ini berusaha memahami bagaimana langkah-langkah dari penanganan penyakit, sehingga dengan pemahaman yang baik ODHA tetap menjalani pengobatan. Pemahaman dalam penelitian ini berupa jenis pengobatan, waktu konsumsi obat, efek samping pengobatan dan waktu kontrol ke VCT.
Kedua informan dalam penelitian ini menyatakan bahwa tempat pengambilan obatan di RSUD Cilacap. Pengambilan obat dilakukan sebulan sekali sekaligus untuk berkonsultasi berkaitan dengan keluhan yang dirasakan dengan tenaga kesehatan yang ada di VCT. Prosedur yang dilalui informan untuk mengambil obat dimulai dari pendaftaran dan setelah mendapatkan karcis informan langsung ke klinik VCT, kemudian menunggu panggilan untuk berkonsultasi dan mengambil obat seperti pernyataan dibawah ini:

“....pertama ya ndaftar habis itu dapet kaya karcis terus ke VCT ngga perlu ngantri karna udah biasa sebulan sekali si nanti ketemu diperiksa kalo ngga konsultasi skalian terus kasih resep buat ambil obat terus ya pulang aku kan jauh mba kecuali ada yang nitip..." ( informan 1)

“.....ya ndaftar kaya biasanya trs dapet kertas no pendaftaran langsung ke VCT di periksa konsul kalo antri ya nunggu terus ambil obat sama klo ada yang nitip diambilin skalian habis itu pulang..."(informan 2)

Pernyataan kedua informan dibenarkan oleh pendamping informan dan petugas di klinik bahwa informan harus mendaftar terlebih dahulu di klinik didampingi pendamping kemudian setelah mendapat karcis langsung ke klinik VCT untuk mengambil obat ke petugas dan sebelumnya dikonseling terlebih dahulu. Kedua informan merupakan penduduk diluar wilayah kabupaten klinik VCT.

Pengobatan ARV ini dapat dilakukan untuk menurunkan jumlah virus HIV/AIDS yang ada di tubuh. Efek samping yang dirasakan bermacammacam baik secara fisik dan psikososial seperti ungkapn informan dibawah ini:

" ....awal minum rasanya ndak enak banget trs lama kelamaan bosen kaya beban gitu tapi harus diminum sampe seumur hidup awal minum aku seminggu lebih lemes ditempat tidur aja tapi itu memang katanya bakal dapat efek samping kaya gitu awal-awal minum..." (informan 1) 
“.... Ya pertama ga enak terus rasanya kaya nya mbekas terus dilidah, bosen ma mikir apa iya tiap hari kaya gini ya tp mau gimana lagi kudu minum seumur hidup dan sensasi awal minum gatal terus sering pusing sama kalau BAB warnanya pekat tapi itu katanya merupakan eek sampingnya ya "(informan 2)

Pernyataan kedua informan dibenarkan oleh pendamping informan dan petugas di klinik bahwa awal-awal minum ARV informan mengalami lemas tubuh dan gatal. Pemahaman ARV merupakan salah satu hal yang sangat penting harus dimiliki oleh ODHA. Hasil penelitian ini menunjukan bahwa semua informan memahami seluruh tahapan pengobatan . Pemahaman tersebut meliputi jenis obat, efek samping obat dan kunjungan ke VCT. Informan dalam penelitian ini mendapatkan ARV lini pertama neviral (Nevirapin) dan Duviral (Zidovudin dan Lamivudin). Seluruh informan yang mengkonsumsi ARV lini pertama dengan jenis obat Neviral Duviral pernah mengalami efek samping pusing, mual dan muntah. Penelitian ini sesuai dengan penelitian yang dilakukan Dianti (2014) bahwa terdapat efek samping yang sering terjadi gatal-gatal dan mual muntah. Efek samping tidak hanya secara fisik aja yang dialami tetapi dari segi psikososial juga ada yaitu stress, bosan, merasa terbebani dan tersiksa sama halnya yang dialami informan. Hasil penelitian ini sejalan dengan penelitian Sari, Endah, Kahija (2014) bahwa efek samping dari ARV menyebabkan mengalami sakit secara psikis dan maupun fisik. Kondisi ini memunculkan stress baru karena kondisi tubuh yang mengalami efek samping dari minum ARV. ${ }^{[7,8]}$

Motivasi minum ARV yang mempengaruhi ODHA menjalani pengobatan yaitu motivasi dari diri sendiri dan orang lain. Orang lain merupakan motivasi pengaruh bagi tambahan yang sangat berpengaruh bagi ODHA biasanya diperoleh dari keluarga, pendamping dan tenaga kesehatan. Motivasi dari diri sendiri merupakan hal yang berpengaruh bagi ODHA untuk tetap menjalani minum ARV ini, hal ini sesuai dengan pernyataan dibawah ini:

"...obat besar manfaatnya buat ningkatin kualitas hidup apalagi aku ini masih muda kan mba,banyak juga yang meninggal karna putus minum obat ya walaupun itu takdir ya terus saya juga kerja..."(partispan 1)

“....Minum ARV ini banyak manfaatnya bisa nyambung hidup ya ibaratny mencoba untuk bertahan hidup apalagi saya kerja dengan punya penyakit ini pokoknya ya usaha lah ya mba minum $A R V$ ini walau kadang mikir sampe kapan dan siap meninggal kapan saja...' (informan 2)

Semua informan dalam penelitian ini memiliki motivasi yang kuat untuk tetap sehat bertahan hidup sehingga bisa melakukan aktivitas sehari-hari menjadikan motivasi tersendiri dari ODHA. Motivasi yang dimiliki ODHA juga ada andil dari para petugas klinik dan pendamping hal tersebut disampaikan oleh petugas ketika mereka melakukan konseling selalu diselipkan kalimat-kalimat yang menumbuhkan motivasi diri untuk ODHA. Hasil penelitian ini didukung oleh Yuniar (2013) yang menyebutkan motivasi dari dalam diri ODHA untuk sembuh dan bertahan hidup merupakan alasan kepatuhan minum ARV. Optimisme hidup ODHA merupakan motivasi hidup, semngat bekerja dan pikiran yang positif (Danistya, 2012). ${ }^{[9,10]}$

Dukungan Minum ARV adalah dukungan yang diperoleh informan karena akan mempengaruhi kepatuhan dalam minum ARV. Dukungan merupakan doa yang tersembunyi dan mampu memberikan semangat tersendiri bagi ODHA. Seluruh informan mendapat dukungan dari keluarga, teman pendamping ODHA dan dari tenaga kesehatan, seperti ungkapan informan dibawah ini:

“ ....untungnya keluarga sama petugas disini membantu keyakinan untuk minum ARV biar bisa bertahan hidup jadi aku ngrasa didukung orang lain juga ditambah klo ketemu sesame teman di 
VCT jadi saling menguatkan juga dan berbagi ..."(partispan 1)

"...Petugas disini membantu menyakinkan orang tua keluarga akhirnya keluarga memberikan dukungan dan aku jadi lebih kuat menjalani pengobatan ini apalagi klau lg obat biasanya disini juga banyak yang ambil obat mungkin usianya juga ada yang lebih tua dariku juga salng menyemangati satu sama lain jadi lebih tenang...' (informan 2)

Dukungan merupakan suatu bentuk motivasi serta menjadi kekuatan tersendiri bagi ODHA. Menurut Sarafino (2011) menyatakan bahwa dengan adanya dukungan dari social maka akan menciptakan lingkungan yang kondusif sehingga memberikan motivasi dan wawasan bari bagi ODHA. Dalam penelitian ini informan didukung oleh keluarga, pendamping, petugas kesehatan dan sesama ODHA yang lain untuk tetap menjalankan pengobatan yaitu minum ARV karna ARV diminum selama hidupnya. ${ }^{[11]}$

Keluarga menjadi sumber kekuatan dan dukungan yang utama bagi ODHA dalam menjlani pengobatan. Semua informan dalam penelitian ini mendapat dukungan keluarga seperti orang tua, sodara dan sesama ODHA yang dianggap seperti keluarga. Hal ini sesuai dengan penelitian Payuk, Arsunan dan Zulkifli (2012) menyatakan bahwa ODHA yang memiliki dukungan keluarga cukup memiliki kualitas hidup yang baik, berbanding terbalik dengan ODHA yang dukungan keluarganya kurang. Petugas kesehatan di ruangan VCT merupakan ujung tombak dari pelayanan ODHA, dengan adanya dukungan positif dari tenaga kesehatan diharapkan ODHA mempunyai kualitas hidup yang baik sehingga tetap melakukan pengobatan. Hal ini didukung penelitian lain yang dilakukan oleh Payuk, Arsunan, Zulkifli (2012) menyatakan bahwa ada hubungan petugas kesehatan dengan kualitas hidup ODHA. Odha yang mendapat dukungan dari petugas kesehatan memiliki proporsi kalitas hidup yang baik. Hal ini juga diungkapkan oleh petugas klinik bahwa dukungan keluarga juga harus didapatkan oleh ODHA dan petugas membantu menyampaikan kepada kelurga tentang kondisi ODHA sehingga kelurga tersebut juga memberikan dukungan secara mental. ${ }^{[12]}$

Harapan informan mulai dari diri sendiri (ingin menikah, ada obat yang mampu menyembuhkan, ingin sehat dan sembuh) dan lingkungan sekitar. Hal ini diungkapkan oleh informan sebagai berikut:

“.....aku cewe ya pengin nikah, nantinya punya anak ya mba kya cewe- cewe yang lain lah terus ada obat yang bikin sembuh kaya penyakit yang lain sama sehat itu aja lah semoga tercapai ya mba doanya aja..." ( informan 1)

“....harapanku ada obat yang menyembuhkan aku sehat lagi terus menikah ma pujaan hati punya anak dan bahagia ma keluarga..aamiin doanya ya mba..." (informan 2)

Semua informan dalam penelitian ini tetap memiliki harapan untuk dirinya sendiri serta lingkungan sekitar. Harapan untuk diri sendiri dari harapan ingin menikah, ada obat yang menyembuhkan dan sembuh dari penyakit ini. Hal ini di dukung juga dar para petugas klinik dan pendamping bahwa ODHA memiliki harapan yang besar untuk sembuh dan hidup selayaknya orang lain yang tidak terkena HIV/AIDS. Hal ini didukung juga dengan penelitian Sukarja, Endang dan Nursisati yang mengungkapkan bahwa pengalaman ODHA pada saat melalui kondisi kritis masih memilik harapan untuk sembuh. Harapan untuk lingkungan sekitar yaitu harapan untuk bisa menikah dan dan memiliki anak. Hasil penelitian ini didkung dengan adanya penelitian Mirzawati (2013) tentang kebermaknaan hidup pada ODHA perempuan yang memiliki harapan serta tujuan bagi ODHA yaitu hidup lebih lama untuk bisa menjaga anak dan mendapatkan kesembuhan. $[13,14]$ 
4. Kesimpulan

Penelitian tentang pengalaman ODHA remaja dalam minum ARV telah melibatkan dua partisipan. Semua partisipan dalam penelitian ini melakukan berbagai tahapan penatalaksanaan pengobatan dan tetap patuh minum ARVsehingga tetap sehat dan menjalani aktivitas sehari-hari. Motivasi dari diri sendiri dan dukungan keluarga serta petugas kesehatan dan lingkungan sekitar mendorong untuk tetap minum ARV untuk keberlangsungan hidup sehat dan meningkatkan kualitas hidup.

\section{Ucapan Terima Kasih}

Peneliti mengucapkan terimakasih kepada UPT Penelitian dan Pengabdian Masyarakat STIKES Al-Irsyad AlIslamiyyah Cilacap, RSUD Cilacap atas terselenggara penelitian ini.

\section{Daftar Pustaka}

[1] Brooks GF, Caroll KC, Butel JS, Morse SA, Mietzner TA, Jawets M, et al. Mikrobiologi kedokteran. Edisi ke-25. Jakarta: Penerbit Buku Kedokteran EGC. 2010

[2] Riyarto S, Wijayanti Y, Indriani C, Wilasto N, Lazuardi E, Mahendradatta Y. Faktor-faktor yang mempengaruhi keterlambatan diagnosis HIV dan AIDS di Yogyakarta, Solo, dan Semarang. Yogyakarta: Universitas GajahMada. 2010

[3] Conrad., P. Leiter, V. Health and Health Care as Social Problems. Oxford. Rowman and Littlefield Publisher. 2003

[4] Hadisetyono B. Hak Kesehatan Penderita HIVIAIDS : Kendala-kendala yang dihadapi Penderita HIV/AIDS dalam Memperoleh Obat- obat Antiretroviral sebagai Pelaksanaan Paten oleh Pemerintah. Jakarta: Universitas Indonesia. 2007

[5] Rahmadini, Y., Retnosari, A., \& Rizka, A. Perbandingan efikasi beberapa kombinasi Antiretroviral pada pasien HIV/AIDS ditinjau dari kenaikan jumlah CD4 rata-rata (Analisis data rekam medis di RSK Dharmais Jakarta tahun 2005-2006). Jakarta: Pharmaceutical Sciences and Research. 2008: 5 (2). http://journal.ui.ac.id

[6] Permatasari, D. Terapi farmakologis pasien Acquired Immune Deficiency Syndrome dengan diare kronik dan stomatitis. Lampung: Medula Unila. 2014. 2 (3), 31-37. http://juke.kedokteran.unila.ac.id

[7] Dianti, E.S. Evaluasi efek samping Antiretroviral pada pasien HIVIAIDS di RSUP Dr. Sardjito Yogyakarta periode tahun 20092013. 2014. http://etd.repository.ugm.ac.id

[8] Sari F, Endah K D dan Y. F. Kahija, I. Makna Perilaku Minum Obat pada Pasien HIV/AIDS Rawat Jalan Di VCT RSUP DR Kariadi Semarang. Semarang: Jurnal Psikologi UNDIP. 2014. Vol. 13 No 2Oktober 2014;190-195.

[9] Yuniar Y, Handayani RS, Aryastami K. Faktor-Faktor Pendukung kepatuhan orang dengan HIV AIDS (ODHA) dalam minum obat antiretroviral di kota Bandung dan Cimahi. Bandung: Journal penelitian kesehatan. 2012; 41:72-83.

[10] Danistya, F. Optimisme hidup penderita HIV/AIDS. Semarang: Jurnal Psikologi, 2012. 1 (1). http://journal.unnes.ac.id/sju/index. $\mathrm{php} / \mathrm{dcp}$

[11] Sarafino, E. Health psychology: biopsychosocial interactions. (7th ed). Canada: John Wiley \& Sons, Inc. 2011

[12] Departemen Kesehatan Direktorat Jenderal Pembinaan Kesehatan Masyarakat Direktorat Bina Gizi Masyarakat. Laporan Penyusunan Pedoman Pemberian Kapsul Vitamin A Dosis Tinggi. Jakarta: Bakti Husada. 2000

[13] Sukarja, I. M., Endang, S., \& Nursiswati. Pengalaman orang dengan HIVIAIDS (ODHA) 
pada saat melalui kondisi

kritis akibat AIDS. 2011.

http://jurnal.unpad.ac.id/jkp/articl

e/dow nload/1317/1301

[14] Mirzawati, N. Kebermaknaan hidup ODHA (Orang Dengan

HIV/AIDS) wanita di Kota

Bukittingi. 2013.

http://ejournal.unp.ac.id 